DOI: 10.15393/j9.art.2019.6121

УДК 821.161.1.09“19”

Д. Б. Терешкина

Российская академия народного хозяйства и государственной службы при Президенте РФ (Великий Новгород, Российская Федерация)

terdb@mail.ru

\title{
«Не зная, куда мы идем, и забыв, откуда мы вышли»: русские в рассказе Гайто Газданова «Панихида»
}

Аннотация. Г. Газданов - один из ярких представителей литературы русского зарубежья, в которой особенно явно звучали темы духовного единения соотечественников. В статье дается анализ рассказа Г. Газданова «Панихида» (1960) в аспекте «христианского реализма», предложенного как эстетический принцип В. Н. Захаровым. Актуальность этого исследования заключается в раскрытии ведущей идеи рассказа, в котором главной темой становится богослужебное слово как основа родовой памяти. Предложен тезис об особой роли языка молитвенного текста как озвучивающего ключевые моменты жизни человека и осмысляющего их в русле общенародной традиции. Именно в ней человек чувствует себя причастным жизни других людей, связанных с ним прежде всего родной речью. Через церковнославянское слово к герою приходит понимание сути единства русскоязычных людей, оказавшихся за пределами родины. Результаты исследования базируются на рассмотрении феномена русских и роли русского языка в иноязычной среде. Прочно сохраняясь в памяти и актуализируясь в необходимые моменты, богослужебное слово становится сигналом общности русских и выражением сути их надмирного (вневременного, внесоциального) существования.

Ключевые слова: Газданов, «Панихида», христианский реализм, богослужебное слово, русское зарубежье, языковая общность

Об авторе: Терешкина Дарья Борисовна - доктор филологических наук, профессор кафедры кадровой политики и управления персоналом, Российская академия народного хозяйства и государственной службы при Президенте РФ (ул. Германа, 31, г. Великий Новгород, Российская Федерация, 173003)

Дата поступления: 14.03.2019

Дата публикации: 18.10 .2019

Для цитирования: Терешкина Д. Б. «Не зная, куда мы идем, и забыв, откуда мы вышли»: русские в рассказе Гайто Газданова «Панихида» // Проблемы исторической поэтики. - 2019. - Т. 17. — № 4. - С. 326-344. DOI: 10.15393/j9.art.2019.6121

(ㄱ Д. Б. Терешкина, 2019 
X ристианский характер русской литературы «полнее всего $X<$...> раскрылся в литературе русского зарубежья, которая жила памятью былой христианской России, лелеяла исторический образ Святой Руси», - писал в 1994 г. В. Н. Захаров [Захаров, 1994: 8]. Русская «литература изгнания» - та часть отечественной словесности, которая, будучи оторванной от своей родной земли, наиболее остро ощущала потребность в определении того, что именно может называться основообразующим началом русского как целостного феномена.

Проблеме единства русских за пределами России и основам их духовного родства посвящен рассказ Гайто Газданова «Панихида». Он был впервые опубликован в Нью-Йорке - в № 59 «Нового журнала» за 1960 г. На родине писателя рассказ был издан 18 ноября 1988 г. в газете «Литературная Россия». Вошедший в рубрику «Из неопубликованного и забытого», он был сопровожден рисунком Л. Рябинина и небольшим вступлением Ст. Никоненко, в котором публикатор знакомил советских читателей с Гайто Газдановым и его творчеством. С тех пор рассказ не раз отмечен критикой [Сапрыкин], признан литературным шедевром [Вахитова], [Рожек]. Вновь обратиться к рассказу побуждает намерение рассмотреть его как текст, поднимающий общечеловеческую проблему смысла жизни, но раскрытом на русском феномене.

Небольшое по объему произведение повествует о жизни русских в Париже во время оккупации его фашистами. Центральное событие рассказа - православное священнодействие, панихида. Эмигранты из России, разные по социальному положению, уровню образования и роду занятий, разобщенные лихим военным временем, проявившим в них отрицательные качества (спекулянтство, мотовство на фоне всеобщей нищеты, пособничество вражеской армии и др.), собираются на панихиде по одному из них - Григорию Тимофеевичу. Батюшка-эмигрант решил отпеть не известного ему человека, оказавшегося его земляком, по полному, монастырскому обряду. В организованном хоре пришедшие на заупокойную службу русские эмигранты вдруг являют удивительное единение и согласие, без единой ошибки исполнив панихиду на церковнославянском языке. 
В рассказе Газданова «Панихида» обнаруживаются такие константы поэтики и идей русскоязычной литературы, как соборность [Есаулов, 1995], пасхальность [Захаров, 2012: 110115, 116-127], [Есаулов, 2004], «минейный код» русской словесности [Терешкина, 2015], «русскость», как бы ни было неуловимо это понятие, языковая и ментальная общность. Именно этот рассказ упомянул академик Н. И. Толстой в предисловии к учебнику церковнославянского языка, вышедшему в начале 1990-х гг., для иллюстрации того, «как глубоко был воспринят русскими людьми или людьми русской культуры церковнославянский язык во времена, которые сейчас кажутся почти патриархальными» [Толстой: 6].

В «Панихиде» Газданова проблема русского как феномена не ставится напрямую, но решается в рамках художественного изображения в целом комплексе констант, считываемых как приметы «русскости». Русская литература, помещенная в чуждую ей среду (как и рассказ, созданный автором вдали от родины), словно сама давала ответ на вопрос о ее сути как литературы национальной. Эту проблему в конце XX в. сформулировал В. Н. Захаров в рамках задачи предлагаемой исследователем этнопоэтики как одной из необходимых дисциплин, «которая должна изучать национальное своеобразие конкретных литератур <...> Она должна дать ответ, <...> что делает русскую литературу русской» [Захаров, 2012: 113].

Восприятие автора рассказа русских людей как феномена - это отстраненный, обособленный взгляд повествователя, отражающий объективное видение событий. Такой взгляд подмечает в русских две их ипостаси: ту, что отражает их материальное бытие, и надмирную, которая сохраняется в представителях этого народа вне зависимости от места их проживания. Существенная доля беспристрастности повествования была обусловлена личностью Гайто Газданова, писателя - осетина по национальности ${ }^{1}$, находившегося далеко от России, скептика и агностика, относившегося к религии более чем критически [Никоненко: 29], [Александрова: 7]. Включенный в мир русских общностью языка, своим мировоззрением автор несколько отстоял от них, усиливая 
оторванность от родины внутренней душевной и (до момента прозрения при панихиде) духовной изоляцией от соотечественников.

Одной из черт при характеристике русских эмигрантов в рассказе становится их страсть к материальным благам, которые стали легкодоступны им в годы испытаний Европы нацистским режимом. До войны, в благополучные времена, эти люди нигде не работали, потому что «жили в состоянии хронического и чаще всего бессознательного бунта против той европейской действительности, которая их окружала»². Они спали в ночлежках и деревянных бараках, исколесили французскую провинцию в поисках заработка и в целом влачили жалкое существование. В годы войны открылась возможность заняться «черной биржей», и русские эмигранты, не раздумывая, стали посредниками между французскими коммерсантами и немецкими покупателями, приобретавшими все без торга и разбора. Так бывшие нищие стали богатыми. Они жили в роскошных парижских квартирах, оставленных хозяевами, носили меха и драгоценности, скупали картины и пировали в ресторанах. Описывая действительность военного времени, автор отмечает «вдруг открывшееся стяжательство» вчерашних бездомных, «никогда, впрочем, не принимавшее западной формы накопления денег» (582). Русские тратили деньги с какимто бездумным размахом и нелепостью, легко расставаясь с тем, что так же легко им доставалось.

Так, один из них - Спиридон Иванович, «высокий унылый человек с черной бородой» - скупил у стекольщика все «барахло», лишь бы тот, предлагавший жителям свои услуги, перестал кричать на улице, мешая ему пить коньяк в парижском кафе. В эмоциональном порыве герой говорит со стекольщиком на русском языке, всюду чувствуя себя «своим»: «Не надрывай ты мне душу, Христа ради, замолчи!» (582), - но, опомнившись, переходит на ломаный французский и, решив «проблему», возвращается к своему уединенно-тоскующему созерцанию мира.

Как отмечал А. М. Зверев, для современников круга Газданова «определяющими оказываются понятия неукорененности 
в окружающем мире, своей непреодолимой психологической чужеродности ему и вместе с тем тотальной от него зависимости, поскольку отрыв от прежней (исходно родной) почвы необратим» [Зверев: 58-59]. Парижский топос, о котором пишет исследователь, важен в рассказе потому, что, судя по описанию полярных состояний русских эмигрантов (изгнание с родины и благополучный Париж, мирное и военное время, нищета и богатство), нигде на земле человек не сможет найти «рая», т. е. душевного успокоения. Не сможет он найти и простой человеческой справедливости, из-за утраты которой была покинута родина в поисках лучшей жизни. Ибо несправедливость является признаком человеческого существования вне зависимости от места и времени, внешних условий и исторических катаклизмов. Социальное расслоение, которое остро чувствует рассказчик - alter ego Гайто Газданова, - coxpaняется среди русских и за пределами родной земли («У стойки хорошо одетые люди - шарфы, меховые воротники, выглаженные костюмы - пили коньяк, кофе с ромом и ликеры, ели бутерброды с ветчиной, которой я давно не видал» - 579), и расслоение это уже не спишешь на результат революций и гражданской войны.

Русские, став «хозяевами жизни» в оккупационном Париже, тем не менее не стирают строгую демаркационную линию между собой, православным народом, и католиками, которых они считают чужими по духу. На это указывает один из ключевых эпизодов рассказа, в котором воспроизводится беседа русских эмигрантов Спиридона Ивановича и Володи в парижском кафе:

«- На том свете отдохнешь, Спиридон Иванович, — сказал Володя, атлетический мужчина лет сорока, специалист по золоту. - Стекольщиков там, я так полагаю, не должно быть, какие там стекла? Только облака да ангелы, больше ничего.

- И золота тоже нету, - сказал один из посетителей.

- Это еще неизвестно, - сказал Володя. — Я как-то был в соборе Парижской Богоматери, там кружка висит для пожертвований. Смотрю, а на ней написано: “для душ, находящихся в чистилище”. Значит, в чистилище какие-то средства поступают. 
- Это их католическое дело, - сказал Григорий Тимофеевич. - Деньги-то, конечно, идут на церковь, чтобы молились здесь за тех, которые, как они думают, должны быть в чистилище. Но это ты прав, странно, конечно, написано» (582-583).

Лейтмотивом рассказа становится пение, великой любовью к которому известен русский народ. С Григорием Тимофеевичем (Гришей, или Гришкой, как зовут его окружающие), рассказчик знакомится в тот момент, когда, уже будучи немолодым, Григорий Тимофеевич тяжело болел чахоткой и редко вставал с кровати. Однако пел он «своим глубоким голосом, на котором удивительным образом совершенно не отразилась его болезнь, всевозможные романсы и песни - и меня поражало богатство его репертуара» (581). Пение будет сопровождать Гришу в последний путь и станет главным потрясением для автора, разглядевшего в слаженном хоре вечную русскую душу, не исчезнувшую в потрясениях лихого времени.

Эта русская душа и в далеком от России Париже мучается вечными, «проклятыми» для русских людей вопросами о счастье и смысле жизни. Находясь на пороге смерти, Гриша, переживший когда-то нищету и голод, а теперь ставший обеспеченным, понимает, что так и не нашел в жизни смысла, не осознал, что такое истинное счастье:

«- Живу я теперь хорошо, конечно. Но только вижу, что раньше я неправильно мечтал. Вот, например, помню я одну ночь в Лионе, зимой. Денег нет, работы нет, комнаты нет. Ночевал я на постройке, все-таки крыша, хоть дождь не заливает. Холодно, накрыться нечем. Лежал я тогда, знаете, на досках, не мог заснуть - никак не согреться - и мечтал. Вот, думаю, квартирку бы вам, Григорий Тимофеевич, с центральным, черт возьми, отоплением, кроватку бы с простынями. А вечером жена ужин подает: колбаса, закуска, бифштексы. Вот это была бы жизнь. <...>

А вышло, что все это неправильно. Не в этом дело. Вернее, не только в этом. В чем - не знаю, только знаю, что не в этом. Теперь у меня все это есть: и квартира, и обед, и жена, и даже ванна - живи, не хочу. Но оказывается, все это не то. Я так теперь думаю. <..>> Мне одного жаль: столько лет прожил, а так и не понял, в чем же счастье человеческое? Ну, хорошо - согрелся, закусил, выпил. А дальше?» (584-585). 
Так некрасовский вопрос «кому на Руси жить хорошо?» в годы массовой русской эмиграции начала XX в. вырос до масштабов мира, и по-прежнему на него невозможно было найти ответа.

Незадолго до смерти Григорий Тимофеевич покупает картину. Как потом сообщает рассказчик, это была копия с полотна Рубенса «Похищение Ганимеда». Рассказ о картине, несомненно, не является случайной вставкой - как и все детали у Газданова, он кажется органичным «слепком с натуры». Мифологический сюжет о Ганимеде (похищение Зевсом Ганимеда, юного сына троянского царя Троса и нимфы Каллирои, из-за его красоты) не известен Григорию Тимофеевичу. «Изображен там, Василий Иванович, огромный орел, и куда-то он летит, а у него на спине, понимаешь, такой молодой юноша, которого он вроде как уносит. Не совсем понятно, правда, но орел, я тебе скажу, лучше не бывает» (581), так описывает герой своему приятелю изображенное на картине. Ни названия, ни имени художника Григорий Тимофеевич не запомнил. Для героя это все не является важным составляющим ценности картины, в своем рассказе о ее приобретении он оговаривает только стоимость: «Деньги за нее такие заплатил - вспомнить страшно» (581). Интерес для Григория Тимофеевича состоял лишь в сюжете полотна, в центре которого для него был орел - только из-за его красоты и мощи было приобретено это произведение живописи.

Необходимо уточнить, что кисти Рубенса принадлежат две картины на сюжет о похищении Ганимеда: ранняя (ок. 1612 г.) [Королева: 36] и поздняя (ок. 1636 г.). Они значительно отличаются друг от друга изображением главного героя, орла. Кроме того в позднем варианте отсутствуют второстепенные персонажи. В рассказе нет детального описания картины, приобретенной Григорием Тимофеевичем, но, судя по упоминаемым деталям (прежде всего, синеватому отливу цвета крыльев орла), можно предположить, что имеется в виду ранний вариант полотна (1611-1612 гг.), где орел занимает значительное место, а фигура Ганимеда гораздо более мужественна и красива, чем на поздней картине (1636-1637 гг.), созданной для охотничьего замка Торре де ла Парада под Мадридом [Королева: 112-113]. 
В эпизоде с картиной Рубенса важны некоторые моменты, которые как нельзя лучше раскрывают характер русского человека с его типичными чертами, в каком бы месте мира он ни находился.

Увидев картину, Гриша восхищен («у меня дыхание захватило» - 581). В этом видно не раз отмечавшееся «очарование» русских необъяснимой и не понятной им красотой (см. об этом: [Лосский: 86-87]). Грише неважно, какое событие греческой мифологии изображено на полотне, при этом он торжественно заявляет, что «сюжет очень роскошный» (581). Этот «сюжет» Гриша придумывает сам, и в нем орел занимает героя больше всего. Простодушное очарование красивой картинкой, в которую человеком вкладывается свой, нужный ему в определенный момент, смысл, отражает еще одну типично русскую черту: присвоение любого мирового явления и освоение его как органичную часть своего мира (см. об этом: [Лихачев: 17-18], [Васильев, Малышев]).

Орел становится для Гриши центром картины неслучайно. В традиционной русской культуре орел принадлежит к семантически положительно оцениваемой птице, хотя и имеющей амбивалентные свойства. «Орел - общепризнанный царь птиц и владыка небес» [Гура: 610]. В новозаветное время орел занимает особое место как символ апостола Иоанна; много раз упоминается в Ветхом Завете, а также в Откровении Иоанна Богослова. Природные свойства орла как благородной птицы с уникальным зрением и уединенным образом жизни на возвышенных местах легли в основу сравнений с ним самого Христа. Еще в XVI в. Максим Грек в толковании на псаломский стих «обновится яко орля юность твоя» (Пс. 102:5) писал: «Орел велик Христос есть, крила же его - Новый и Ветхий Завет, имиже Христова церкви Божия подымаема и подмогаема, превыше летает всех козней бесовских и живет в пустыни, сиречь в тишине и безмолвии, не боящися еретических шатаний и бурных навет их» [Максим Грек: 21]. Орел становится символом прорыва ввысь, на небо, в горние сферы. И уносит он на картине не какого-то неведомого Грише юношу, а, согласно символике рассказа, самого героя - такого же, как на картине Рубенса: смятенного, испуганного, застигнутого врасплох, 
в чем мать родила, ибо «у савана карманов нет», уносит туда, где, видимо, «знают», чего ему «в жизни было нужно». Неслучайно рассказчик, придя на похороны Гриши, словно увидел именно это:

«В гробу, покрытом цветами, лежало тело Григория Тимофеевича, одетое в черный костюм, и мертвое его лицо смотрело, казалось, в то небо, куда поднимается орел, уносящий Ганимеда» (586).

Гайто Газданов часто описывал смерть, границу между бытием и небытием человека (см. об этом: [Никоненко: 29], [Mаханьков: 124], [Шабурова], [Проскурина]). «В своей прозе Газданов пытается найти единство Смерти и Жизни», - справедливо пишет Е. В. Кузнецова [Кузнецова: 161]. Это единство является рассказчику в умершем, в момент смерти ставшим другим человеком («вот жил Гриша, а умер другой человек, Григорий Тимофеевич» - 585): уходящие в мир иной отличаются от остающихся в земном другим знанием о смерти знанием отmуда. Эта граница всегда страшила и манила человека; в творчестве Гайто Газданова она стала лейтмотивом.

Именник русских эмигрантов, не изменившийся в чужой среде, составляет своеобразное сообщество «своих», где по традиции представителей незнатного рода называют уменьшенным именем, независимо от возраста, и где трепетно относятся к имени, данному человеку при рождении, и имени по отцу.

Главный герой, Гриша, Гришка, называется автором-рассказчиком полным именем, Григорий Тимофеевич, в котором в равной степени важно значение как собственного имени, так и патронима. Тимофей - «почитающий Бога», Григорий - в буквальном переводе «бодрствующий» - одно из наиболее частотных имен у русских. Бодрый, ищущий дух сохранил Григорий Тимофеевич при слабеющем от недуга теле. Род занятий другого героя, Володи, «специалиста по золоту», отчасти оправдывает этимологию имени Владимир (от иерк.-слав. «владеющий миром»), ибо золото во все времена имело власть над людьми в их земных отношениях. Спиридон Иванович, носящий имя с затемненной этимологией (по одной из версий, Спиридон - «незаконнорожденный» 
от греч. - см.: [Суперанская: 205]), как будто не оставлен в своей «безродности», ибо по отцу он Иоаннович, т. е. «помилованный Богом». Ни одно имя не вводится в произведение непреднамеренно: «Русские писатели охотно крестили своих литературных героев, давая им неслучайные христианские имена и фамилии» [Захаров: 113].

Фамилий в рассказе «Панихида» нет, и это тоже обоснованно. Как «незаконнорожденный» Спиридон Иванович, русские в изгнании словно оказались «без роду и племени», утратив свои семейные, фамильные имена. И в момент, когда отдавал Богу душу один из них, им настало время понять, как сообща, вспомнив о своем родстве не по крови, а по Духу, проводить своего собрата в последний путь.

В день панихиды квартира Гриши была полна цветочных венков, неизвестно откуда добытых Володей в голодную и холодную парижскую зиму 1943-го. В комнате, где лежал умерший Григорий Тимофеевич, собрались все русские, знавшие Гришу:

«- Ждем батюшку, — тихо сказал Володя.

Батюшка, старый человек с хрипловатым от простуды голосом, приехал через четверть часа. На нем была поношенная ряса, вид у него был печальный и усталый. Он вошел, перекрестился, губы его беззвучно произнесли какую-то фразу. <...>

- Из каких мест покойный? - спросил священник.

Володя ответил - такого-то уезда, Орловской губернии.

- Сосед, значит, - сказал батюшка. - Я сам оттуда же, и тридцати верст не будет. Вот беда, не знал я, что земляка хоронить придется. А как звали?

- Григорий.

Священник молчал некоторое время. Видно было, что эта подробность - то, что покойный был из тех же мест, что и он, произвела на него особенное впечатление» (586).

Память об общей земной родине приводит священника к мысли о воссоединении с душой умершего земляка через Божественное слово, которое поможет почившему воцариться в Небесных селениях - истинной родине христиан, где, по вере каждого из них, они вечно будут пребывать земляками:

«Потом священник вздохнул, снова перекрестился и сказал:

- Будь бы другие времена, я бы по нем настоящую панихиду отслужил, как у нас в монастырях служат. Да только вот голос 
у меня хриплый, одному мне трудно, так что тут дай Бог хоть короткую панихиду совершить. Может быть, кто-нибудь из вас все-таки поможет, подтянет? Поддержит меня?

Я взглянул на Володю. Выражение лица у него было такое, каким я себе никогда не мог бы его представить - трагическое и торжественное.

- Служите, батюшка, как в монастыре, - сказал он, - а мы вас поддержим, не собьемся.

Он обернулся к своим товарищам, поднял вверх обе руки повелительным и привычным, как мне показалось, жестом, священник посмотрел на него с удивлением, - и началась панихида.

Нигде и никогда, ни до этого, ни после этого я не слышал такого хора. Через некоторое время вся лестница дома, где жил Григорий Тимофеевич, была полна людьми, которые пришли слушать пение. Хрипловатому и печальному голосу священника отвечал хор, которым управлял Володя» (586).

Володя берет на себя роль руководителя хора, отбивающего такт согласного пения. Симфония голосов раскрывает соборный дух русского народа, где каждый голос в отдельности ведет свою партию и в то же время является частью общего хора. Этот образ вписан не только в хронотоп парижской квартиры; он знаком каждому православному русскому, молящемуся соборной молитвой на литургии независимо от времени и места ее совершения. Чувство духовного единения с братьями по вере отменяет время и саму смерть, ибо конечна жизнь лишь одного человека - жизнь рода во Христе вечна. И этот век - не сотня лет земной жизни поколений, а тысячелетие русского воцерковления, которое невозможно отменить годами и десятилетиями разобщения и рассеивания по миру в результате распада государства.

Слово Христово становится основой единения народа, воспринимающего Его как воплощение Христа (Ин. 1: 1-3, 14). Это вновь обретенное русскими эмигрантами Слово возвращает их в лоно свое, являя ту истинную жизнь, которую не мог обрести Григорий Тимофеевич и которую с удивлением созерцает рассказчик:

«Никогда я не чувствовал с такой судорожной силой, что ни в чем, быть может, человеческий гений не достигал такого 
страшного совершенства, как в этом сочетании раскаленных и торжественных слов с тем движением звуков, в котором они возникали» (587).

В этой связи важным оказывается наблюдение Ласло Диенеша, одного из издателей первого собрания сочинений Гайто Газданова: «Можно думать об эмиграции не как о несчастье, а как о новой жизни, о новой задаче, даже как о некоем освобождении. <...> “Мы не в изгнании, мы в послании”. Так говорили и в это верили многие» [Диенеш: 8].

В панихиде по рабу Божьему Григорию рассказчик улавливает наиболее поразившие его слова. Это седален по третьей песне канона и стихиры Иоанна Дамаскина (глас 2 и 8), самые печальные во всей службе, говорящие о тщете и суете мира. Но завершают словесный ряд панихиды для автора главные слова молитвы «Со святыми упокой...», оставляющие надежду на продолжение жизни души в вечной радости с насельниками Царствия Божия. Проницательным является наблюдение Д. Сапрыкина, обращавшегося к этому рассказу Газданова: «Богослужебный хор ведь есть, может быть, наиболее явный на земле образ “жизни будущего века”, в котором смерти уже не будет. Тогда ангелы и люди будут ликовать составят лики, то есть хоры, славящие Бога. И герои рассказа, несчастные эмигранты, потерявшие земное отечество, в заупокойном пении вновь соединяются со своими предками во образ нового и вечного Отечества» [Сапрыкин: 192-193].

По прошествии времени все происходившее на панихиде рассказчик воспринимает как видение:

«И после того, как прошло некоторое время, мне начало казаться, что ничего этого вообще не было, что это было видение, кратковременное вторжение вечности в ту случайную историческую действительность, в которой мы жили, говоря чужие слова на чужом языке, не зная, куда мы идем, и забыв, откуда мы вышли» (588).

Здесь обнаруживается интуитивное обращение к древнему жанру видения, в котором совершающееся чудо воспринимается как явление вечности в сиюминутном мире. У повествователя эта вечность связана с церковнославянским словом Божественной службы и, через него, - с не понятым им Христом, Который для русских есть живое слово Божие, где 
бы эти русские ни находились. По наблюдениям Э. Александровой, «обретение подлинного существования или иллюзия этого обретения, “превращение”, происходящее с человеком, казалось бы, внешне ничем не объяснимое, внутренние движения личности оказываются в центре целого ряда газдановских рассказов» [Александрова: 7]. Этому внезапному «преображению» своих знакомцев поражается рассказчик. На его удивленный вопрос, откуда взялось такое согласие в случайно составленном хоре, Володя отвечает:

«- Да просто так. $<\ldots>$ Кто в опере когда-то пел, кто в оперетке, кто просто в кабаке. И все в хоре пели, конечно. А уж церковную службу мы с детства знаем - до последнего вздоxa» (588).

Ключевые слова - «с детства» и «до последнего вздоха» Володя говорит невзначай. Ситуативно семантически для него не связанные, они охватывают всю жизнь русского православного человека - от Таинства Крещения до заупокойной по нем службы и посмертного поминовения.

Слово во Христе оказывается тем, что связывает православных русских. В земном, материальном, русские похожи друг на друга, но оно же их и разделяет. Рассказчик ощущает родство с соплеменниками только тогда, когда чувствует единение с ними в Духе, не совсем, впрочем, ему самому понятном - как и первым его читателям, судя по меткому и многозначному замечанию Г. Адамовича: «Главное у него (Г. Газданова. - Д. Т.) не люди, а то, что их связывает, то, чем заполнена пустота между отдельными фигурами, - бытие, стихия, жизнь, не знаю, как это назвать» [Никоненко: 29].

«Вечная память...» - важнейшие слова православной панихиды. Эти слова следует понимать и в смысле родовой, генетической памяти русского православного народа, явленной прежде всего в Божественном слове. В свете отслуженной у гроба новопреставленного Григория панихиды и открывается подлинный и глубокий сюжет рассказа Газданова. В момент встречи со смертью одного из своих ближних герой-рассказчик обретает смысл объединяющего русских начала. Оно заключено в сакральном слове родного языка, объясняющего 
человеку предназначение его жизни и смысл смерти как ухода к Богу, Который Сам есть Слово.

\section{Примечания}

1 Русский язык для Г. Газданова был родным, о чем он сам писал литературоведу А. А. Хадарцевой (см.: [Никоненко: 15]).

2 Газданов Г. Панихида // Газданов Г. Собр. соч.: в 3 т. М.: Согласие, 1996. Т. 3. С. 580. Далее ссылки на это издание приводятся в тексте статьи с указанием страницы в круглых скобках.

3 В свете этих наблюдений вряд ли приходится согласиться с комментарием к эпизоду рассказа, в котором упоминается о картине позднего Рубенса: «Это была копия рубенсовского "Похищения Ганимеда", написанного почти одновременно с картиной Рембрандта на тот же сюжет (1636-1637 гг., “Ганимед” Рембрандта - 1635 г.)» (832).

\section{Список литературы}

1. Александрова Э. Гайто Газданов: возвращение на Родину // Газданов Г. Княжна Мэри: Рассказы. - СПб.: Издательская группа «Лениздат», 2012. - C. 5-12.

2. Бердяев Н. А. Судьба России. - М.: Эксмо-Пресс, Харьков: Фолио, 1998. - $736 \mathrm{c}$.

3. Васильев С. В., Малышев С. И. О национальной культуре России и национальном характере россиян // Васильев С. В., Малышев С. И. Этика государственной службы. Политико-философский аспект. - Великий Новгород, 2003. - С. 37-50.

4. Вахитова Т. М. Газданов Гайто // Русская литература XX века. Прозаики, поэты, драматурги: биобиблиограф. словарь. - М.: ОЛМА Медиа Групп, 2005. - С. 443-446.

5. Газданов Г. Панихида // Новый журнал. - 1960. - № 59. - С. 9-19.

6. Газданов Г. Панихида // Литературная Россия. - 1988. — № 46 (1346). C. $16-17$.

7. Газданов Г. Панихида // Газданов Г. Собр. соч.: в 3 т. - М.: Согласие, 1996. - Т. 3. - С. 579-588.

8. Газданов Г. Княжна Мэри: Рассказы. - СПб.: Издательская группа «Лениздат», 2012. - 320 с.

9. Гура А. В. Символика животных в славянской народной традиции. - М.: Индрик, 1997. - 912 с.

10. Диенеш Л. Писатель со странным именем // Газданов Г. Собр. соч.: в 3 т. - М.: Согласие, 1996. - Т. 1. - С. 5-12.

11. Есаулов И. А. Категория соборности в русской литературе. - Петрозаводск: Изд-во ПетрГУ, 1995. - 287 с.

12. Есаулов И. А. Пасхальность русской словесности. - М.: Кругъ, 2004. $560 \mathrm{c}$. 
13. Захаров В. Н. Русская литература и христианство // Проблемы исторической поэтики. - Петрозаводск, 1994. - Вып. 3. - С. 5-11 [Электронный ресурс]. — URL: http://poetica.pro/journal/article.php?id=2370 (24.03.2019). DOI: 10.15393/j9.art.1994.2370

14. Захаров В. Н. Проблемы исторической поэтики. Этнологические аспекты. - М.: Индрик, 2012. - 264 с.

15. Зверев А. М. Парижский топос Газданова // Возвращение Гайто Газданова: научная конференция, посвященная 95-летию со дня рождения. 4-5 дек. 1998 г. - М.: Русский путь, 2000. - С. 58-66.

16. Королева А. Ю. Рубенс. - М.: ОЛМА Медиа Групп, 2010. - 128 с.

17. Кузнецова Е. В. О некоторых направлениях в изучении литературного наследия Г. Газданова // Известия ВГПУ. - 2008. — № 10 [Электронный pecypc]. — URL: https://cyberleninka.ru/article/n/o-nekotoryh-napravleniyahv-izuchenii-literaturnogo-naslediya-g-gazdanova (17.02.2019).

18. Лихачев Д. С. Раздумья о России. - СПб.: Изд-во Logos, 1999. - 672 с.

19. Лосский Н. О. Характер русского народа: в 2 кн. - Франкфурт-наМайне: Посев, 1957. - Кн. 1. - 152 с.

20. [Максим Грек] Сочинения преподобного Максима Грека, изданные при Казанской духовной академии: [в 3 ч.]. - 2-е изд. - Казань: Типолитография Императорского ун-та, 1897. - Ч. 3. - 296 с.

21. Маханьков Е. А. Малая проза Г. Газданова как объект литературоведческих исследований: некоторые итоги и перспективы // Русская филология. Вестник Харьковского национального педагогического университета имени Г. С. Сковороды. - 2014. - № 1-2 (51). - С. 120-125.

22. Никоненко Ст. Загадка Газданова // Газданов Г. Собр. соч.: в 3 т. М.: Согласие, 1996. - Т. 1. - С. 13-36.

23. Проскурина Е. Н. Художественная философия смерти в новеллистике Г. Газданова // Сибирский филологический журнал. - 2016. — № 2. C. $72-82$.

24. Рожек Л. Творчество Гайто Газданова в контексте европейской литературной традиции // Pisarze nowi, zapomniani i odkrywani na nowo. 1996. - С. 94-107.

25. Сапрыкин Д. Л. Рассказ Газданова «Панихида» и религиозные корни творчества // Возвращение Гайто Газданова: Науч. конф., посвященная 95-летию со дня рождения. 4-5 дек. 1998 г. - М.: Русский путь, 2000. - C. 187-193.

26. Суперанская А. В. Современный словарь личных имен: Сравнение. Происхождение. Написание. - М.: Айрис-пресс, 2005. - 384 с.

27. Терешкина Д. Б. «Четьи-Минеи» и русская словесность Нового времени. - Великий Новгород: Изд-во НовГУ им. Ярослава Мудрого, 2015. - 332 c.

28. Толстой Н. И. Предисловие к первому изданию // Плетнева А. А., Кравецкий А. Г. Церковнославянский язык. - 4-е изд. - М.: Изд. совет РПЦ, 2006. - С. 3-6. 
29. Шабурова М. Н. Тема смерти в ранних рассказах Газданова // Возвращение Гайто Газданова: научная конференция, посвященная 95-летию со дня рождения, 4-5 дек. 1998 г. - М.: Русский Путь, 2000. - С. 164-168.

Daria B. Tereshkina

The Russian Presidential Academy of National Economy and

Public Administration

(Novgorod the Great, Russian Federation)

terdb@mail.ru

\title{
"In Ignorance of Where We Head for and in Disregard of Where We Come from": the Russians in the Story "The Requiem" by Gaito Gazdanov
}

\begin{abstract}
The article offers the analysis of Gazdanov's story "The Requiem" (1960) in the context of "Christian realism" put forward by V. N. Zakharov as an aesthetic principle. The themes of the spiritual solidarity of compatriots were expressed especially in the literature of the Russian expatriate community. The importance of the article resides in disclosing of a leading idea of the story which main topic is the liturgical word as the basis of the ancestral memory. The thesis about a particular role of the prayer text language as that one expressing the key moments of a human's life and comprehending them in the terms of a nationwide tradition is brought forward. It is in the nationwide tradition where a person feels involved in other people's life related to him first via his native speech. By means of the Church Slavic language the protagonist comes to the understanding of the core of the unanimity of the Russian speaking people who ended up outside their motherland. The results of the research are based on the study of the phenomenon of the Russians and the role of the Russian language in alien conditions. Kept in the memory and becoming actual as necessary the liturgical word becomes a sign of the unity among the Russians and expression of the essence of their transcendent (non-temporal, extra-social) existence.
\end{abstract}

Keywords: Gazdanov, “The Requiem”, Christian realism, liturgical word, Russian expatriate community, language community

About the author: Tereshkina Daria B. - Doctor of Philology, Professor of the Department of Personnel Policy and Personnel Management, The Russian Presidential Academy of National Economy and Public Administration (RANEPA) (Branch in Novgorod the Great) (ul. Germana 31, Novgorod the Great, 173003, Russian Federation)

Received: March 14, 2019

Date of publication: October 18, 2019 
For citation: Tereshkina D. B. "In Ignorance of Where We Head for and in Disregard of Where We Come from": the Russians in the Story "The Requiem" by Gaito Gazdanov. In: Problemy istoricheskoy poetiki [The Problems of Historical Poetics], 2019, vol. 17, no. 4, pp. 326-344. DOI: 10.15393/j9.art.1994.2370 (In Russ.)

\section{References}

1. Aleksandrova E. Gaito Gazdanov: Return to the Motherland. In: Gazdanov G. Knyazhna Meri: Rasskazy [Gazdanov G. Princess Mary: Stories]. St. Petersburg, Lenizdat Publ., 2012, pp. 5-12. (In Russ.)

2. Berdyaev N. A. Sud'ba Rossii [The Destiny of Russia]. Moscow, Eksmo-Press Publ., Kharkov, Folio Publ., 1998. 736 p. (In Russ.)

3. Vasil'ev S. V., Malyshev S. I. About National Culture of Russia and National Character of the Russians. In: Vasil'ev S. V., Malyshev S. I. Etika gosudarstvennoy sluzhby. Politiko-filosofskiy aspekt [Vasiliev S. V., Malyshev S. I. The Ethics of Public Service. Political and Philosophical Aspect]. Novgorod the Great, 2003, pp. 37-50. (In Russ.)

4. Vakhitova T. M. Gazdanov Gaito. In: Russkaya literatura XX veka. Prozaiki, poety, dramaturgi: biobibliograficheskiy slovar' [Russian Literature of the 20th Century. Prose Writers, Poets, Play Writers: a Bio-bibliographic Dictionary]. Moscow, OLMA Media Grupp Publ., 2005, pp. 443-446. (In Russ.)

5. Gazdanov G. Requiem. In: Novyy zhurnal [The New Review], 1960, no. 59, pp. 9-19. (In Russ.)

6. Gazdanov G. Requiem. In: Literaturnaya Rossiya, 1988, no. 46 (1346), pp. 16-17. (In Russ.)

7. Gazdanov G. Requiem. In: Gazdanov G. Sobranie sochineniy: $v 3$ tomakh [Gazdanov G. Collected Works: in 3 Vols]. Moscow, Soglasie Publ., 1996, vol. 3, pp. 579-588. (In Russ.)

8. Gazdanov G. Knyazhna Meri: Rasskazy [Princess Mary: Stories]. St. Petersburg, Lenizdat Publ., 2012. 320 p. (In Russ.)

9. Gura A. V. Simvolika zhivotnykh v slavyanskoy narodnoy traditsii [The Symbolism of Animals in Slavic Folk Tradition]. Moscow, Indrik Publ., 1997. 912 p. (In Russ.)

10. Dienesh L. A Writer with a Strange Name. In: Gazdanov G. Sobranie sochineniy: $v 3$ tomakh [Gazdanov G. Collected Works: in 3 Vols]. Moscow, Soglasie Publ., 1996, vol. 1, pp. 5-12. (In Russ.)

11. Esaulov I. A. Kategoriya sobornosti v russkoy literature [The Category of Sobornost' in Russian Literature]. Petrozavodsk, Petrozavodsk State University Publ., 1995. 287 p. (In Russ.)

12. Esaulov I. A. Paskhal'nost' russkoy slovesnosti [Paskhal'nost' of Russian Literature]. Moscow, Krug Publ., 2004. 560 p. (In Russ.)

13. Zakharov V. N. Russian Literature and Christianity. In: Problemy istoricheskoy poetiki [The Problems of Historical Poetics]. Petrozavodsk, 1994, issue 3, pp. 5-11. Available at: http://poetica.pro/journal/article.php?id=2370 (accessed on March 24, 2019). DOI: 10.15393/j9.art.1994.2370 (In Russ.) 
14. Zakharov V. N. Problemy istoricheskoy poetiki. Etnologicheskie aspekty [The Problems of Historical Poetics. Ethnological Aspects]. Moscow, Indrik Publ., 2012. 264 p. (In Russ.)

15. Zverev A. M. Paris Topos of Gazdanov. In: Vozvrashchenie Gayto Gazdanova: nauchnaya konferentsiya, posvyashchennaya 95-letiyu so dnya rozhdeniya. 4-5 dekabrya 1998 g. [Return of Gaito Gazdanov: Scientific Conference Dedicated to the 95th Anniversary of His Birth. December 4-5, 1998]. Moscow, Russkiy put' Publ., 2000, pp. 58-66. (In Russ.)

16. Koroleva A. Yu. Rubens. Moscow, OLMA Media Grupp Publ., 2010. 128 p. (In Russ.)

17. Kuznetsova E. V. About Some Directions in the Study of the Literary Heritage of G. Gazdanov. In: Izvestiya Volgogradskogo gosudarstvennogo pedagogicheskogo universiteta [Ivzestia of the Volgograd State Pedagogical University], 2008, no. 10. Available at: https://cyberleninka.ru/article/n/onekotoryh-napravleniyah-v-izuchenii-literaturnogo-naslediya-g-gazdanova (accessed on February 17, 2019). (In Russ.)

18. Likhachev D. S. Razdum'ya o Rossii [Thoughts About Russia]. St. Petersburg, Logos Publ., 1999. 672 p. (In Russ.)

19. Losskiy N. O. Kharakter russkogo naroda: $v 2$ knigakh [The Character of the Russian People: in 2 Books]. Frankfurt am Main, Posev Publ., 1957, book. 1. 152 p. (In Russ.)

20. Maksim Grek. Sochineniya prepodobnogo Maksima Greka, izdannye pri Kazanskoy dukhovnoy akademii: $v 3$ chastyakh [The Writings of St. Maxim the Greek, Published at the Kazan Theological Academy: in 3 Parts]. Kazan, Tipo-litografiya Imperatorskogo universiteta Publ., 1897, part 3. 296 p. (In Russ.)

21. Makhan'kov E. A. Small G. Gazdanov's Prose as an Object of Literary Studies: Some Results and Perspectives. In: Russkaya filologiya. Vestnik Khar'kovskogo natsional'nogo pedagogicheskogo universiteta imeni G. S. Skovorody [Russian Philology. Bulletin of H. S. Skovoroda Kharkiv National Pedagogical University], 2014, no. 1-2 (51), pp. 120-125. (In Russ.)

22. Nikonenko St. The Enigma of Gazdanov. In: Gazdanov G. Sobranie sochineniy: $v 3$ tomakh [Gazdanov G. Collected Works: in 3 Vols]. Moscow, Soglasie Publ., 1996, vol. 1, pp. 13-36. (In Russ.)

23. Proskurina E. N. The Artistic Philosophy of Death in the Novellistics of G. Gazdanov. In: Sibirskiy filologicheskiy zhurnal [Siberian Journal of Philology], 2016, no. 2, pp. 72-82. (In Russ.)

24. Rozhek L. The Creativity of Gaito Gazdanov in the Context of the European Literary Tradition. In: Pisarze nowi, zapomniani i odkrywani na nowo [New, Forgotten and Re-discovered Writers], 1996, pp. 94-107. (In Russ.)

25. Saprykin D. L. The Gazdanov's Story "Requiem" and Religious Roots of the Creativity. In: Vozvrashchenie Gayto Gazdanova: nauchnaya konferentsiya, posvyashchennaya 95-letiyu so dnya rozhdeniya. 4-5 dekabrya $1998 \mathrm{~g}$. [Return 
of Gaito Gazdanov: Scientific Conference Dedicated to the 95th Anniversary of His Birth. December 4-5, 1998]. Moscow, Russkiy put' Publ., 2000, pp. 187-193. (In Russ.)

26. Superanskaya A. V. Sovremennyy slovar' lichnykh imen: Sravnenie. Proiskhozhdenie. Napisanie [A Modern Dictionary of Personal Names: Comparison. Origin. Spelling]. Moscow, Ayris-press Publ., 2005. 384 p. (In Russ.)

27. Tereshkina D. B. "Chet'i-Minei» $i$ russkaya slovesnost' Novogo vremeni ["Chet'i-Minei" and Russian Literature of Modern Times]. Novgorod the Great, Yaroslav-the-Wise Novgorod State University Publ., 2015. 332 p. (In Russ.)

28. Tolstoy N. I. Preface to the First Edition. In: Pletneva A. A., Kravetskiy A. G. Tserkovnoslavyanskiy yazyk [Pletneva A. A. Kravetsky A. G. The Church Slavonic Language]. Moscow, Publishing Council of the Russian Orthodox Church, 2006, pp. 3-6. (In Russ.)

29. Shaburova M. N. The Theme of Death in the Early Stories of Gazdanov. In: Vozvrashchenie Gayto Gazdanova: nauchnaya konferentsiya, posvyashchennaya 95-letiyu so dnya rozhdeniya. 4-5 dekabrya $1998 \mathrm{~g}$. [Return of Gaito Gazdanov: Scientific Conference Dedicated to the 95th Anniversary of His Birth. December 4-5, 1998]. Moscow, Russkiy put' Publ., 2000, pp. 164168. (In Russ.) 